open@Access

\title{
The UAE Tour, cycling stars, and Twitter: Tweeting as part of promoting the host country
}

\author{
Authors' contribution: \\ A) conception and design \\ of the study \\ B) acquisition of data \\ C) analysis and interpretation \\ of data \\ D) manuscript preparation \\ E) obtaining funding
}

Received: 22.10 .2020

Accepted: 05.08 .2021

\author{
Jiří Zákravský* A-E \\ Department of Politics and International Relations, Faculty of Arts, University of West \\ Bohemia, Pilsen, Czech Republic
}

*Correspondence: Jiří Zákravský, Department of Politics and International Relations, Faculty of Arts, University of West Bohemia, Jungmannova 1, Plzeň, 301 000; email: jirkazak@kap.zcu.cz

\begin{abstract}
Using the example of the 2019 inaugural UAE Tour, this study demonstrates how cycling stars indirectly promote countries hosting globally watched sporting events through their Twitter accounts. This study presents a qualitative and quantitative content analysis of the Twitter activity of selected cycling stars. However, this promotion is only a secondary result of their activity on social media; professional athletes use their Twitter accounts as a platform for self-presentation and to show their daily lives to fans. If the athletes are active on social media, it is almost impossible for them to avoid speaking about the host countries, indirectly evaluate them, and provide information about them to their followers. While sports celebrities' social media profiles are a limited space for the promotion of host countries, they can also help improve the image of the countries and present them in a positive light. Of course, political leaders use countless public or sports diplomacy tools to promote their countries abroad, and online platforms are not necessarily a key element in the promotion of their international image.
\end{abstract}

Key words: Sports diplomacy, UAE, cycling, Twitter

\section{Introduction}

According to public opinion, the phenomena of sport and politics should not be mixed. However, this demand or wish does not reflect reality, as mentioned by Barrie Houlihan (2014, p. 5) and Lincoln Allisson (1993, p. 5). Sport is very often used by politicians to fulfil political goals. In both democratic and undemocratic regime systems, politicians do not hesitate to use this connection. However, the aims and tools of using sport are different from case to case. Nonetheless, sport and sports success have the ability "[...] to bring with it international prestige, aid the building of national identity and engender a 'feel good' factor among the population" (Dennis \& Grix, 2014, p. 1).

In the area of international relations, sport is seen as a useful soft power tool and therefore a tool for public diplomacy (Black \& Peacock, 2013, p. 709; Murray, 2018, p. 113). It is also possible to speak about the existence of sports diplomacy as a specific subcategory of public diplomacy. Sports diplomacy is described as using “" [...] sports people and sporting events to engage, inform, and create a favourable image amongst foreign publics and organizations to shape their perceptions in a way that is more conducive to achieving a government's foreign policy goals" 
(Murray, 2012, p. 581). There are a few tools that can be used in sports diplomacy. However, hosting famous sporting events is probably the most influential among them (Zákravský, 2016, p. 26), especially hosting sports megaevents such as the Olympic Games and FIFA World Cups (Grix, 2018, p. 159). Unfortunately for the host countries, the majority of sporting events do not obtain a global audience. However, this does not mean that the host countries do not use these sporting events as a sports diplomacy tool (Black, 2008, p. 468).

One of the many sporting events that have taken place in the Middle East is the UAE Tour. In 2019, this road cycling race was established as a result of the merging of the Dubai Tour and the Abu Dhabi Tour. When the UAE Tour was established, Aref Hamad Al Awani (quoted in Passela, 2018), the General Secretary of Abu Dhabi Sports Council, spoke openly about the importance of the race in the context of introducing the United Arab Emirates at a global level: "The Abu Dhabi and Dubai Tours were both successful, now the UAE Tour is stronger to create a bigger impact all-round and provide the worldwide television audience to discover new areas and locations in the country." Nowadays, the UAE Tour is the only UCI World Tour race in the Middle East region. This is very important for the host country because the best cycling teams (with the most popular cyclists in their squads) participate in the competition. Thus, some of the most famous road cyclists compete on Emirati soil and can indirectly help promote the UAE, ${ }^{1}$ which is not considered to be a free country by many, including the NGO Freedom House (2019).

The most famous cyclists could be described as heroes or stars; these two words "[...] are closely tied and are frequently used as synonyms" (Povedák, 2014, p. 7). Many historical cycling heroes are still remembered by fans, even though many fans did not witness their races in person. For instance, nearly every Italian cycling fan admires the wellknown battles between Fausto Coppi and Gino Bartali. In Belgium, they hope a new champion such as Eddy Merckx will soon arise. The French search for the successors to the last French Tour de France winners Bernard Hinault, Lauren Fignon, and "the Eternal Second," Raymond Poulidor. There are also many cycling fans worldwide who speak about "the Fallen Angel," Lance Armstrong. However, greater fan attention is paid to contemporary cycling stars and celebrities. In the field of professional cycling competition, celebrities can be defined as "[...] the public identities that embody their sport in the general public media as well as being objects of aspiration and consumption to their fans" (Kiernan, 2018, p. 44). For example, cycling celebrities are typically winners of Grand Tours, three-week-long cycling races across France (Tour de France), Italy (Giro d'Italia), and Spain (Vuelta a España); the most famous one-day races called the Monuments; or the World Championships. They may also be sprinters, the fastest cyclists in the world.

In the past, journalists created the image of athletes (Holt \& Mangan, 1996, p. 11) and described their incredible performance, awesome wins, or crushing losses; they influenced how athletes and sporting events were described (Pedersen, 2014, p. 104). Originally, many fans did not have the possibility to watch their favorite sports stars or communicate with them; they could only obtain a more or less detailed description of the competition published in dailies or magazines. Live broadcasting and television extension partly broke the monopoly of sports journalists as the image-makers of athletes. However, the majority of professional athletes, not only cyclists, currently use new media and social networking sites for their communication with the public. This allows them to present themselves in the way they want to be seen by fans. Therefore, "through social media, athletes promote and emphasize aspects of their identity that would be difficult to transmit using traditional media channels" (Sanderson, 2013, p. 419). Thus, their image does not depend only on newspapers and the qualities and moods of sports journalists; the athletes can construct or even reconstruct their own image. They have become producers of their self-presentations in cyberspace and in real life, as Erving Goffman (1956) describes in his great contribution to social science. In the end, it is possible to say that "new media have amplified fan-athletes interaction significantly and irrevocably" (Sanderson \& Kassing, 2014, p. 247). In the $21^{\text {st }}$ century, the images of athletes are highly influenced by their selfpresentations via social media, where they try to prove their "[...] positive characteristics in an effort to engender favorable impressions [...]" (Lebel \& Danylchuk, 2012, p. 466).

In the world of professional cycling, Twitter, a micro-blogging tool where users write and share 280-character messages called tweets, is probably the most popular new medium. According to the Cycling News website (2011), the cyclists "[...] show that social media can give the fans unprecedented access to the thoughts of professional riders." From 2011 to 2015, readers of Cycling News voted for the Twitter Personality. The popularity of Twitter among professional cyclists has been so high that some cycling teams have decided to implement an internal Twitter policy to control riders' activity on this platform. For example, in 2012, the Belgian squad Omega Pharma-QuickStep decided that their riders could not "[...] send Twitter messages out before an hour after the finish" (Cycling News, 2012). In sum, "many athletes and coaches use Twitter to directly reach fans and manage information" (Laucella, 2014, p. 96) as well as to communicate with the public.

\footnotetext{
${ }^{1}$ For more information about political developments in the UAE, see Almezaini, 2012.
} 
This article focuses on the fact that famous athletes are more or less indirectly exploited by the city and country hosting a sporting event to help fulfil its political goals. In the context of this study, the UAE Tour should not be perceived only as a sporting event, but also as a sporting event that has political implications and is used as an Emirati sports diplomacy tool to promote the UAE abroad. The cyclists participating in the UAE Tour were able to inform their fans and followers about their stay on Emirati soil via Twitter and, in this indirect way, refer to the existence of the UAE and its local landscape, nature, or people all without mentioning the internal problems of the Emirates. This means that cycling stars (or their media managers, who administrate cyclists' social media profiles), who are followed by many fans, can help promote and construct a more positive image for the country abroad. This is not done intentionally; it is rather a secondary output of their self-presentation on Twitter through tweets about their everyday life, not only their lives in the professional peloton. Using the example of the inaugural UAE Tour, this study aims to show how cycling stars can indirectly help promote the host country of a sporting event via their Twitter accounts.

To fulfil this aim, the study responds to the following questions:

1) Did the cycling stars tweet about the UAE Tour?

2) How did they refer to the host country of the UAE?

3) Were the tweets about the UAE Tour positive, neutral, or negative?

The following section briefly introduces a literature review of research on athletes using social media during sporting events. The questions mentioned above are introduced in detail in the subsequent part of the article, which focuses on methodology and explains the methodological process of this research. The main part of the article follows, which contains a content analysis of tweets and retweets of selected cycling stars published on their official Twitter accounts.

\section{Athletes, social media, and politics: A literature review}

An increasing percentage of the world's population is active on social media. As of January 2021, the most popular platforms are Facebook, with 2,740 million users; YouTube, with 2,291 million; Instagram, with 1,221 million; and Twitter, with 353 million (Statista, 2021). These numbers include professional athletes who use social media to communicate with each other or with fans (see e.g., Pegoraro, 2010; Sanderson \& Kassing, 2014; Feder, 2020) for self-presentation (see e.g., Lebel \& Danylchuk, 2012; Reichart Smith \& Sanderson, 2015; Li et al., 2020) as well as for improving their personal brand (see e.g., Geurin, 2017; Su et al., 2020). Similarly, the vast majority of professional sports clubs and competitions or international sports federations use many social media platforms to communicate with the public and craft their image. The global popularity of social media in the world of professional sport has also led to scholarly interest and increased the number of scientific texts in recent years that deal with the use of social media in the sports industry. As pointed out by Samuel López-Carril et al. (2020), prestigious academic journals published 130 scholarly articles focused on social media and sports between 2010 and 2019 ; in the last four years of the examined period, at least 20 were published every year.

Some of these articles dealt with athletes using social media during sports competitions. For instance, Jeffrey W. Kassing and Jimmy Sanderson (2010) described how English-speaking cyclists use Twitter during the Giro d'Italia. Molly Hayes Sauder and Matthew Blaszka (2018) focused on the same social network but analyzed the activities of the U.S. Women's National Football Team players at the 2015 FIFA World Cup. Abuin-Penas et al. (2019) analyzed the activity of Spanish athletes on Instagram during the 2018 PyeongChang Olympic Games. Shohreh Sadeghi and Ho Keat Leng (2020) focused on the self-presentation of Iranian football players on Instagram during the 2018 World Cup, while Andrea N. Geurin and Erin L. McNary (2021) examined athletes' marketing activities on Instagram during the 2016 Summer Olympics.

Studies on the subject of athletes' use of social media in relation to the sporting event in which they participate are relatively common. Nonetheless, there is a research gap of studies focusing primarily on athletes' activities on online social networks during international competitions held in countries with undemocratic regimes. How do athletes reflect, if at all, on the fact that there is a democratic deficit in the host country? Is this a topic reflected in any way in their activity on social media? This study of the activities of selected cyclists during the inaugural 2019 UAE Tour seeks to answer precisely these questions.

\section{Methodology: What, who, when, and how?}

The following steps were taken in the content analysis to answer the research questions and fulfil the aim of the study: 1) defining the Twitter accounts to be analyzed; 2) identifying the research period; 3) collecting tweets and 
retweets (reposts of tweets posted by another Twitter user); 4) and categorizing these tweets and retweets. The following paragraphs introduce the detailed manner in which the content analysis was conducted.

For the purpose of this research, twelve cyclists promoted by the official UAE Tour website were selected. The official UAE Tour website presented about twelve "big name riders" that were to participate in the tour and were expected to attract cycling fans' attention. This study involved “"[...] riders' extended biographies” describing the cyclists' most significant triumphs (The UAE Tour, 2019). All of the cyclists could be labelled as cycling stars; some of them are winners of the general classification at the Grand Tours, several Grand Tour stages, World Championships, Monuments, or local races such as the Dubai Tour and the Abu Dhabi Tour. For details about the twelve cyclists based on the information provided by the official website of the UAE Tour (2019), see Table 1.

Table 1. Cycling Stars According to the UAE Tour

\begin{tabular}{|c|c|c|}
\hline Cyclist & $\begin{array}{l}\text { Nationality } \\
\text { Cycling Team }\end{array}$ & According to the UAE Tour (2019), why is he a cycling star? \\
\hline Alejandro Valverde & $\begin{array}{l}\text { Spain } \\
\text { Movistar Team }\end{array}$ & $\begin{array}{l}\text { "Valverde }[\ldots] \text { is one of the most successful riders in the peloton with } \\
\text { over } 100 \text { pro wins ... includes four Liège-Bastogne-Liège }(2006,2008 \text {, } \\
2015,2017) \text { victories, five at La Flèche Wallonne }(2006,2014-2017) \text {, } \\
\text { one GC at the Vuelta a España ..., the UCI Road World." }\end{array}$ \\
\hline Chris Froome & $\begin{array}{l}\text { Great Britain } \\
\text { Team Sky }\end{array}$ & $\begin{array}{l}\text { "Froome is s the first rider after Bernard Hinault to win the Tour, La } \\
\text { Vuelta and the Giro in a row (across } 2017 \text { and 2018). His palmares } \\
\text { also includes six Tours de France, one Vuelta a España, and last year's } \\
\text { Giro d'Italia. Froome is one of only six cyclists who have won all } \\
\text { three Grand Tours." }\end{array}$ \\
\hline Vincenzo Nibali & $\begin{array}{l}\text { Italy } \\
\text { Bahrain Merida }\end{array}$ & $\begin{array}{l}\text { "Nibali }[. . .] \text { is one of the greatest ever all rounders, being one of only } \\
\text { six cyclists to have won all three Grand Tours: the Vuelta a España in } \\
2010 \text {, the Giro d'Italia in both } 2013 \text { and } 2016 \text { and the Tour de France } \\
\text { in 2014." }\end{array}$ \\
\hline Tom Dumoulin & $\begin{array}{l}\text { Netherlands } \\
\text { Team Sunweb }\end{array}$ & $\begin{array}{l}\text { "In } 2017 \text { he became the first Dutch cyclist ever to win the Giro } \\
\text { d'Italia and [...] both the World Individual Time Trial and the World } \\
\text { Team Time Trial Championships. His palmares features stage wins } \\
\text { in all three Grand Tours [...], and a silver medal at the Rio Olympic } \\
\text { Games." }\end{array}$ \\
\hline Rohan Dennis & $\begin{array}{l}\text { Australia } \\
\text { Bahrain Merida }\end{array}$ & Dennis is "[...] the best time trialist in the peloton." \\
\hline Michał Kwiatkowski & $\begin{array}{l}\text { Poland } \\
\text { Team Sky }\end{array}$ & $\begin{array}{l}\text { Kwiatkowski's "[...] achievements include the } 2014 \text { road World } \\
\text { Championship, the } 2017 \text { Milano-Sanremo, two editions of the Strade } \\
\text { Bianche, the } 2015 \text { Amstel Gold Race, and the General Classification } \\
\text { at the } 2018 \text { Tirreno-Adriatico." }\end{array}$ \\
\hline Elia Viviani & $\begin{array}{l}\text { Italy } \\
\text { Deceuninck - Quick Step }\end{array}$ & "Viviani [...] was 2018 's most successful rider with 18 victories." \\
\hline Fernando Gaviria & $\begin{array}{l}\text { Columbia } \\
\text { UAE Team Emirates }\end{array}$ & "Gaviria is one of the best sprinters in the peloton." \\
\hline Marcel Kittel & $\begin{array}{l}\text { Germany } \\
\text { Team Katusha Alpecin }\end{array}$ & "Kittel’s palmares includes 86 victories." \\
\hline Alexander Kristoff & $\begin{array}{l}\text { Norway } \\
\text { UAE Team Emirates }\end{array}$ & $\begin{array}{l}\text { "Kristoff [...] boasts major victories such as the } 2014 \text { Milano-Sanremo } \\
\text { and the } 2015 \text { Tour of Flanders." }\end{array}$ \\
\hline Mark Cavendish & $\begin{array}{l}\text { Great Britain } \\
\text { Dimension Data }\end{array}$ & $\begin{array}{l}\text { "Cavendish has won } 15 \text { stages at the Giro d'Italia, a mighty } 30 \text { at the } \\
\text { Tour de France, and three at the Vuelta a España [...] he became UCI } \\
\text { Road World Champion, and boasts one-day-race successes such as } \\
\text { Milano-Sanremo (2009)." }\end{array}$ \\
\hline Caleb Ewan & $\begin{array}{l}\text { Australia } \\
\text { Lotto Soudal }\end{array}$ & $\begin{array}{l}\text { "Ewan is a talented sprinter who claimed } 11 \text { professional victories in } \\
\text { his first season." }\end{array}$ \\
\hline
\end{tabular}


Furthermore, all the selected cycling stars have official Twitter accounts, and they used them for their communication with the public. However, the number of followers influences the impact of the cyclists' tweets, and there is a significant difference between the most followed and the least followed professional cyclists inside this group. For details, see Table 2.

Table 2. Cyclists' Twitter Followers

\begin{tabular}{lc}
\hline Cyclist & Number of Twitter followers \\
\hline Chris Froome & $1,510,000$ \\
Mark Cavendish & $1,410,000$ \\
Vincenzo Nibali & 571,000 \\
Alejandro Valverde & 428,000 \\
Marcel Kittel & 245,000 \\
Tom Dumoulin & 188,000 \\
Fernando Gaviria & 131,000 \\
Michał Kwiatkowski & 124,000 \\
Alexander Kristoff & 50,000 \\
Elia Viviani & 49,000 \\
Rohan Dennis & 29,000 \\
Caleb Ewan & 19,000 \\
\hline
\end{tabular}

Note: As of February 21, 2019, the number of Twitter followers is rounded to the nearest 1,000; Source: Own, based on the official Twitter accounts of the professional cyclists.

"the UAE Tour" or "the Emirates" in their tweets or retweet. Accordingly, the analysis focuses on the words used in their posts on Twitter, which are limited to 280 characters.

Second, the study targeted the hashtags used by the cyclists. "Hashtags represent a way of indicating textually keywords or phrases especially worth indexing [... and] by using the \# character to mark particular keywords, Twitter users communicate a desire to share particular keywords folksonomically" (Halavais, 2014, p. 36). Tim Highfield (2014) examined the use of the hashtag "\#tdf” during the 2012 Tour de France and pointed out the global audience of the cycling race across France. In this case, it was supposed that hashtags such as "\#UAE," "\#UAETour," and "\#Emirates" could be part of the examined tweets and retweets.

Third, the analysis worked with replies and mentions of other Twitter accounts. In tweets, users can mark other users with the "@" character and Twitter account name. The user is then notified that somebody has mentioned them, replied to their tweet, or just wants to ask them for something. In this study, it was expected that the selected professional cyclists would tag the official Twitter account of the UAE Tour, @ uae tour, and then their followers could see the UAE Tour Official Twitter account. By opening or following this account, followers could find information not only about the race, but also about the Emirati nation.

Fourth, attention was paid to the images and videos contained in the tweets and retweets. Images or short videos are often part of Twitter posts and "add a visual dimension" (Marwick \& Boyd, 2011, p. 148) to tweets and retweets. Thus, tweets and retweets including images and videos can be more credible for Twitter users than tweets or retweets without them (Pittman \& Reich, 2016, pp. 157-158). It was assumed that the cyclists would probably add images or videos referring to the UAE Tour or the UAE to their tweets. For instance, Jeffrey W. Kassing and Jimmy Sanderson (2010, p. 122) mentioned that during the Giro d'Italia in 2010, the professional cyclists often published photos related to the race on their Twitter accounts. In this regard, no differences were expected between the 2010 Giro d'Italia and the 2019 UAE Tour.

Fifth and finally, the use of emojis is a popular technique for communicating on social media. Emojis allow social media users, including Twitter users, “[...] to describe objects, situations and even feelings with small images, providing a visual and quick way to communicate" (Barbieri et al., 2016, p. 3967). They often contain small images 
of faces, animals, food or drink, flags, or activities, and they are quite popular in microblogging and online written communication. It was presumed that the cyclists would mainly use the emoji of the UAE flag around the time of the UAE Tour.

The analysis worked only with the first category - the category of tweets and retweets mentioning the UAE in the manner described above. These tweets and retweets were sorted into three groups: positive, neutral, and negative. In this context, the content of positive tweets and retweets is connected to admiring the organizational skills, spectators, or routes of the host country. For example, the tweet from Mark Cavendish (2016) praising the Basque fans in the 2016 edition of the Tour de France is a typical tweet from this category. Neutral tweets and retweets only provide information about the cycling race, including, for example, information on results or stage details without any evaluation. In contrast, negative tweets and retweets are critical of the organizers or the lack of fans. For example, Dutch cyclist Bram Tankink (2016) was critical of the organizers of the 2016 Vuelta a España on his Twitter account due to the lack of safety for the cyclists in the final kilometers during Stage 5. Thus, the study is based on a content analysis using both a qualitative and quantitative research approach.

\section{Twitter, cycling stars, and the UAE Tour: The analysis}

In the research period, 57 tweets and 52 retweets were posted on the official Twitter accounts of the selected cyclists. The majority of the tweets -41 tweets, or $71.9 \%$ of all tweets published by the analyzed Twitter users mentioned the UAE or the UAE Tour in some way. The situation was somewhat different for retweets: 25 retweets referred to the UAE Tour, $48.1 \%$ of all retweets. For details, see Table 3.

Table 3. Number of Analyzed Tweets and Retweets

\begin{tabular}{|c|c|c|c|c|c|c|}
\hline \multirow[b]{2}{*}{ Cyclist } & \multicolumn{2}{|c|}{ All tweets and retweets } & \multicolumn{2}{|c|}{$\begin{array}{l}\text { Tweets and retweets mentioning } \\
\text { the UAE or UAE Tour }\end{array}$} & \multicolumn{2}{|c|}{$\begin{array}{c}\% \text { of tweets and retweets mentioning } \\
\text { the UAE or UAE Tour/all tweets and } \\
\text { retweets }\end{array}$} \\
\hline & Tweets & Retweets & Tweets & Retweets & $\%$ of tweets & $\%$ of retweets \\
\hline Fernando Gaviria & 18 & 11 & 18 & 10 & $100 \%$ & $90.1 \%$ \\
\hline Michał Kwiatkowski & 6 & 1 & 6 & 1 & $100 \%$ & $100 \%$ \\
\hline Elia Viviani & 11 & 32 & 4 & 9 & $36.4 \%$ & $28.1 \%$ \\
\hline Alejandro Valverde & 3 & 3 & 3 & 1 & $100 \%$ & $33.3 \%$ \\
\hline Tom Dumoulin & 4 & 1 & 3 & 1 & $75 \%$ & $100 \%$ \\
\hline Alexander Kristoff & 4 & 0 & 3 & 0 & $75 \%$ & - \\
\hline Vincenzo Nibali & 2 & 1 & 2 & 1 & $100 \%$ & $100 \%$ \\
\hline Marcel Kittel & 2 & 0 & 1 & 0 & $50 \%$ & - \\
\hline Chris Froome & 4 & 0 & 1 & 0 & $25 \%$ & - \\
\hline Caleb Ewan & 0 & 2 & 0 & 2 & - & $100 \%$ \\
\hline Rohan Dennis & 2 & 0 & 0 & 0 & - & - \\
\hline Mark Cavendish & 1 & 1 & 0 & 0 & - & - \\
\hline Total & 57 & 52 & 41 & 25 & $71.9 \%$ & $48.1 \%$ \\
\hline
\end{tabular}

Source: Own, based on the official Twitter accounts of the professional cyclists.

Ten of the twelve analyzed Twitter users posted at least one tweet or retweet openly mentioning the UAE Tour. Only the Australian Rohan Dennis (2 tweets and 0 retweets in the research period) and Mark Cavendish, the winner of 30 Tour de France stages ( 1 tweet and 1 retweet), did not refer to the Emirati cycling race. Both finished the competition; however, their participation was quite unsuccessful, and cycling fans had most likely expected this lack of good results. A successful performance could be seen as a great reason to speak about participating in a race via social media. In previous years, Mark Cavendish, one of the most popular cyclists on Twitter, had been very competitive in races in the Middle East, where he won general classifications at the Tour of Qatar in 2013 and 2016, the Dubai Tour in 2015, and several individual stages as well. However, in the 2019 UAE Tour, he returned to racing after two seasons of health issues (O'Shea, 2019), and he was not able to compete with the best sprinters. 
Caleb Ewan was the only professional rider who did not tweet at all. However, he retweeted two posts in the research period that were both connected to the UAE Tour through the hashtag "\#UAETour" or image with the UAE Tour logo and @uae_tour after the Stage 4 victory of the Lotto-Soudal cyclist. The first retweet was originally published by Mar Sergeant (2019), the sports manager of Ewan's team, and the second was posted by Velon (2019), which is a group of professional cycling teams, including Ewan's team, that "would use innovation and technology to increase the value of the sport and create upside revenue to cycling teams" (Van Reeth, 2016, p. 79). Thus, 100\% of Ewan's activity on Twitter was related to the UAE Tour; however, he had the lowest number of followers among the analyzed Twitter accounts and published only two retweets.

Chris Froome, the most successful cyclist on the Grand Tours in the second decade of the $21^{\text {st }}$ century, should have been the brightest cycling star participating in the UAE Tour. The organizers used him to represent the 2019 UAE Tour to fans and journalists. It is clear that Froome (quoted in the UAE Tour, 2018) had only positive words to say about this event: "It should be a fantastic, well-rounded event with a team time trial and two uphill finishes. It should be some exciting racing and a nice, relaxed atmosphere, a good accommodation. It is a nice way to start the season, so I am looking forward to that in February." Unfortunately for the UAE, Froome did not actually come to the country due to changes in his training plan. However, he published this information on his Twitter with a sad face emoji and the UAE flag and mentioned @uae_tour, saying that he "[...] was really looking forward to the TTT \& 2 uphill finishes" (Froome, 2019). This tweet was categorized as positive in this study because Froome showed positive emotions toward the UAE, although he did not visit in 2019. The British cyclist did not only inform his followers about changes in his race calendar, but also said he wanted to go to the Emirates. The phrase "looking forward to" is connected with positive expectations: in this instance, positive expectations for a stay in the UAE. This tweet was retweeted 81 times and obtained 1,081 likes (Froome, 2019).

The four cyclists that followed - Marcel Kittel, Vincenzo Nibali, Alexander Kristoff, and Tom Dumoulin - did not achieve personal victories at the UAE Tour. However, all of them wrote a few tweets or used retweets related to the competition. The majority of their tweets and every retweet published in the research period referred to the UAE Tour. Using@uae_tour or the "\#UAETour" hashtag was a regular part of their tweets. No hashtag or reference to the official Twitter of the UAE Tour was used by Marcel Kittel. Nevertheless, he published two tweets, and one of them was connected to the UAE Tour. His tweet could be categorized as positive because he showed appreciation for the UAE when he said, "Great to be in the Emirates again. Always a good time" (Kittel, 2019); in other words, he suggested that the UAE is a great place to visit. Afterwards, three Twitter users decided to retweet Kittel's tweet, and it obtained 142 likes (Kittel, 2019). Alejandro Valverde, the incumbent road race world champion and another cyclist included in the study, won Stage 3 . All of his tweets were connected to this stage. A commonality among them was the hashtag "\#UAETour." In one tweet, the emoji of the Emirati flag was included (see Valverde, 2019).

Elia Viviani, the winner of Stage 5 at the UAE Tour, owns the most active Twitter account in the research period. He published 11 tweets and 32 retweets; however, only four tweets and nine retweets referred to the UAE Tour $36.4 \%$ and $28.1 \%$ of all his tweets and retweets, respectively. The question thus arises as to why the tweets and retweets mentioning the UAE Tour are in the minority on Viviani's Twitter. When the inaugural UAE Tour took place, the 2019 UCI Track Cycling World Championships in Pruszków, Poland were simultaneously being held. Viviani is also a track cyclist, and he frequently mentioned the results of his compatriots and friends from the Italian national team in his tweets or retweets. On the question of Viviani's UAE Tour tweets and retweets, he regularly used the "\#UAETour" hashtag (on one occasion, he used the "\#UAETour2019" hashtag; Viviani, 2019a) and images or words such as "Dubai," "Abu Dhabi," and "Emirates." Once, he retweeted a message from the official UAE Tour account (UAE Tour Official, 2019). Viviani is the third cyclist who published a positive tweet connected to the UAE. In this tweet, he described the UAE Tour as "another beautiful week [...]" (Viviani, 2019b). Thus, Viviani said that he had spent a very nice week in the UAE; this message, written in Italian, praised the UAE and was retweeted 27 times and obtained 401 likes (Viviani, 2019b).

Michał Kwiatkowski, Team Sky cyclist and former world champion, posted six tweets and one retweet. All of them referred to his participation in the UAE Tour. Mentioning @uae_tour was an integral part of his tweets and the retweet, as were images. One of Kwiatkowski's tweets, the last that he published in the research period, could be categorized as positive. He praised the competition for a "good seven days of racing in@uae_tour" and used the thumbs up emoji (Kwiatkowski, 2019), suggesting that the UAE Tour was a great experience. This message was retweeted 25 times and obtained 499 likes (Kwiatkowski, 2019).

Fernando Gaviria is the last cycling star who was part of this research. In the 2019 UAE Tour, he was a leader of his new team, the UAE Team Emirates. This cycling team was established in 2017, and his "[...] challenge is to represent a whole Nation, the UAE, which are strongly interested in promoting cycling and in presenting as a top 
level sports and cycling hub" (UAE Team Emirates, 2019a). To fulfil their goals, the team invested a significant amount of money in acquiring the services of the cycling stars to participate in the project, with top sprinter Gaviria being one of them. It was very important for the UAE Team Emirates to be successful on their home soil. In the inaugural UAE Tour and in Stage 2, Gaviria won the bunch sprint in Abu Dhabi. It is not a surprise that Gaviria's Twitter account was full of messages related to the UAE Tour and to the UAE. He posted 18 tweets and 11 retweets, and only one retweet was not connected to the UAE Tour - a retweet from the UAE Team Emirates official account when they welcomed a new sponsor (UAE Team Emirates, 2019b). Nearly all of the tweets and retweets mentioned @ uae_tour, the "\#UAETour" hashtag, and images referring to the Emirates. An emoji of the Emirati flag was an integral part of eight of his tweets or retweets. One of his retweets was categorized as positive; it was originally a tweet of the UAE Team Emirates that praised the way of the team presentation in Dubai (UAE Team Emirates, 2019c).

The cyclists referred to the UAE Tour and the UAE in their tweets and retweets in all the mentioned ways. Mentioning@uae_tour was the most popular one and was used 40 times in 66 tweets and retweets $(60.6 \%$ of all tweets and retweets). Thirty tweets and retweets $(45.5 \%)$ included images or short videos easily identifiable as referring to the UAE Tour or the UAE. Words related to the UAE were integral parts of the 29 tweets or retweets $(43.9 \%)$, and the popular hashtag "\#UAETour" emerged in 27 tweets and retweets (40.9\%), while "\#UAETour2019" was included in one. The emoji of the Emirati flag was used 10 times (15.2\%): once by Chris Froome and Alejandro Valverde, and eight times by Fernando Gaviria. For details, see Table 4.

Table 4. How Cyclists Referred to the UAE Tour

\begin{tabular}{|c|c|c|c|c|c|}
\hline Cyclist & Key words & $\#$ & (a) & Image/video & Emoji \\
\hline Fernando Gaviria & + & + & + & + & + \\
\hline Michał Kwiatkowski & + & - & + & + & - \\
\hline Elia Viviani & + & + & + & + & - \\
\hline Alejandro Valverde & - & + & - & + & + \\
\hline Tom Dumoulin & + & + & + & + & - \\
\hline Alexander Kristoff & + & + & - & - & - \\
\hline Vincenzo Nibali & + & - & + & - & - \\
\hline Marcel Kittel & + & - & - & - & - \\
\hline Chris Froome & - & - & + & - & + \\
\hline Caleb Ewan & - & + & + & + & - \\
\hline Rohan Dennis & - & - & - & - & - \\
\hline Mark Cavendish & - & - & - & - & - \\
\hline
\end{tabular}

Note: + means it was part of at least one (re)tweet; - means it was not part of any (re)tweets; Source: Own, based on the official Twitter accounts of the professional cyclists.

The vast majority of the analyzed tweets and retweets, 61 of 66 , were neutral. They provided information about the UAE Tour, the results of the stages, or the personal feelings of the cyclists after the stages. They did not contain any evaluation of the Emirati cycling events. However, this was not the case for the final five posts that positively evaluated the UAE Tour. Chris Froome, Marcel Kittel, Elia Viviani, Michał Kwiatkowski, and Fernando Gaviria (via retweet) posted positive words about the sporting event. They all wrote that they enjoyed racing in the UAE, and Gaviria specifically applauded the team presentation in Dubai. Furthermore, there were no negative tweets or retweets describing the UAE as a hostile place for cycling.

\section{Conclusion and discussion}

In the final part of the study, it is essential to return to the research questions. The answers produced by the content analysis allow for broader conclusions to be made about sporting events hosted by undemocratic regimes, sports stars and social media, and sports diplomacy tools and cyberspace. 
The first research question inquired as to whether the cycling stars tweeted about the UAE tour. Ten of the twelve analyzed Twitter accounts of the cycling stars posted tweets or retweets about the UAE Tour. The majority of their tweets and retweets were frequently connected to the UAE Tour and the host country. The only exception was the Twitter account of Elia Viviani; however, the reason for this difference was discussed above. Thus, when cycling stars participate in races and are active on their Twitter accounts (or on social media in general), it is likely that they will provide information about the race, which could help the host country catch fans' attention.

The second research question inquired how the cyclists referred to the UAE. On social media, there is a wide range of ways to refer to something, such as by using specific words or phrases, mentions, hashtags, emojis, images, or videos. All of these methods could be observed in the analyzed Twitter accounts. The most popular was mentioning@uae_tour. Adding images or videos and using words and phrases related to the UAE or the hashtag "\#UAETour" were similarly popular. However, there are differences among the analyzed Twitter users due to the various ways in which the professional cyclists wanted to present themselves. Some of them used emojis, while others did not. Every Twitter account is different, and social media users tend to use different methods of selfpresentation on these platforms.

The third research question inquired as to whether the tweets about the UAE Tour were positive, neutral, or negative. Most of the tweets and retweets referring to the UAE Tour were neutral, and their authors simply provided information about the sporting events rather than evaluating them. Five posts published on the analyzed Twitter accounts could be categorized as positive, and there were no negative tweets or retweets related to the Emirati cycling race. This is an important finding for the host country as negative opinions of sporting events, which could result for various reasons, are quite often spread further via other social media accounts or mass media, especially when many famous athletes write about them on their accounts. Eventually, this could have the effect of presenting the country in a negative light when the sporting event was actually intended to promote a positive image.

All of this does not mean that the cycling stars wanted to openly promote the UAE Tour and the UAE via their activity on Twitter. Social media are used as platforms on which users can present themselves and construct their image on their own. Twitter is quite popular among athletes, not only within professional cycling. In the era of the network society (Castells, 2010), sports fans want to know nearly everything about sports stars, and social media offer amazing tools for acquiring first-hand information. Many fans follow sports celebrities, and popular athletes are aware of fans' desire for information; they use social media and attempt to meet fans' expectations. For this reason, they are quite active users on these platforms.

Nonetheless, as long as they are not paid for their posts as part of a marketing activity, the promotion of the host country is not based on the calculation of sports stars. Rather, the athletes simply want to give their fans first-hand information about their daily lives. Obviously, professional cyclists compete all over the world. They write or speak about their experience and inevitably mention the host countries of events. Sometimes, undemocratic regimes host events. However, athletes often do not see this as a problem, nor do they speak about it openly. Thus, they can promote the undemocratic host country simply by tweeting or retweeting a message regarding only themselves or their own sporting activity. If a cyclist says that he enjoys the UAE Tour, it is definitely not the same thing as showing support for the undemocratic rule of the UAE. However, undemocratic regimes benefit from this situation just as democratic ones do, especially when a sports celebrity mentions the sporting event and evaluates it in a positive manner on social media, as was seen in the example of a few positive tweets analyzed in this study. Even this kind of information published on social media can spread at least a basic awareness of the host country. Suppose the cycling fans following their cycling hero on Twitter have no information about the UAE whatsoever. In this case, they can gain a basic perspective on this country from a positive message published on the occasion of the inaugural UAE Tour. As has been pointed out by Simon Anholt (2007, pp. 1-2), who has long focused on nation branding, most people do not and cannot have comprehensive knowledge of almost 200 countries. As a result, they judge most countries through stereotypes and partial information they acquire from more or less relevant sources. Even a banality, such as a positive message tweeted by a sports celebrity about a country, can provide fans with at least a piece of information about a country that is not given significant space in the mass media. Thus, the fan's idea of the country can be more or less shaped by this kind of message, even when this is not its primary purpose.

Evidently, a few positive tweets or retweets posted by sports stars do not have the power to improve the complex international image of a host country. Rather, these tweets are just a drop in the ocean; political representatives use countless public or sports diplomacy tools to promote their countries abroad. The social media accounts of sports celebrities are quite limited spaces for promoting host countries. Nevertheless, as the study indicates, the host countries can be seen in a positive light on these platforms, and this can help them construct a slightly more positive image. However, these platforms are not the main way they improve their international image. 
It would be a completely different story if the sports stars used their social media accounts to speak openly against the social and political situation in a given country. In such a case, it would be possible to speak of digital activism on the part of the athletes, the aim of which is to change the current situation (see e.g., Marston, 2017; Schmidt et al., 2019; Ahmad \& Thorpe, 2020). If sports stars openly express criticism of their country of origin, the country in which they live, or the country in which they attend a sporting competition, their objections will be discussed in the international environment. In this context, it is possible to mention the famous New York Rangers ice hockey player Artemi Panarin, who used his official Instagram account to show support for Alexei Navalny, the Russian opposition leader and one of the main critics of Putin's Russia. Panarin replied to a photo of Navalny and his family with the hashtag "\#свободунавальному," which could be translated as "Freedom for Navalny" (Ketko, 2021). Navalny was poisoned in 2020 and survived the attack. However, after returning to Russia, he was arrested and sentenced to several years in prison. Although hockey fans may not be interested in Russian politics, Panarin's statement offers information about Russia's problems. Similarly, supporters following Lewis Hamilton on social media may be primarily interested in his life in the world of Formula 1. However, through his posts they also receive information about the Black Lives Matter movement, which Hamilton supports and which is having a worldwide impact (see e.g., Hamilton, 2021).

These openly critical social media messages can damage the image of the country at which they are aimed. At the same time, similar opinions are viewed as political statements, which the public often claim have no place in sport (see Allison, 1993, p. 5; Houlihan, 2014, p. 5). On the other hand, insignificant positive statements about the host country of an event are not typically perceived as political, even though they can help create a more favorable image of the country. As a result, they ultimately strengthen the country's soft power, which is often the goal of the host country's political leaders.

\section{Competing interests}

No potential conflict of interest was reported by the author.

\section{Funding}

This work was supported by the Institutional support for the long-term conceptual development of the research organization Department of Politics and International Relations, University of West Bohemia in 2020.

\section{Acknowledgements}

The author would like to thank two anonymous reviewers for their constructive insights, which helped to improve this text.

\section{References}

Abuín-Penas, J., Martínez Patiño, M. J. \& Míguez-González, M. I. (2019). Spanish Winter Olympic athlete's communication on Instagram. Journal of Human Sport and Exercise. 14(4), 780-791. DOI: 10.14198/jhse.2019.14.Proc4.40.

Ahmad, N. \& Thorpe, H. (2020). Muslim Sportswomen as Digital Space Invaders: Hashtag Politics and Everyday Visibilities. Communication \& Sport. 8(4-5), 668-691. DOI: 10.1177/21674795519898447.

Almezaini, K. S. (2012). The UAE and Foreign Policy. Foreign aid, identities and interests. Routledge: London.

Allison, L. (1993). The Changing Context of Sporting Life. In L. Allison (Ed.), The Changing Politics of Sport (pp. 1-14). Manchester: Manchester University Press.

Anholt, S. (2007). Competitive Identity. The New Brand Management for Nations, Cities and Regions. Palgrave Macmillan: Basingstoke.

Barbieri, F., Ronzano, F. \& Saggion, H. (2016). What does this Emoji Mean? A Vector Space Skip-Gram Model for Twitter Emojis. Language Recourses and Evaluation Conference, LREC. Retrieved December 18, 2019, from http://www. lrec-conf.org/proceedings/lrec2016/pdf/735_Paper.pdf

Black, D. (2008). Dreaming big: The pursuit of 'second order' games as a strategic response to globalization. Sport in Society. 11(4), 467-480. DOI: 10.1080/17430430802019441

Black, D. \& Peacock, B. (2013). Sport and Diplomacy. In A. F. Cooper, J. Heine, \& R. Thakur (Eds.), The Oxford Handbook of Modern Diplomacy (pp. 708-725). Oxford: Oxford University Press.

Castells, M. (2010). The Rise of the Network Society. Chichester: Wiley-Blackwell. 
Cavendish, M. [@MarkCavendish] (2016, July 9). The Basque fans are, without doubt, the most incredible roadside spectators in the world. So passionate. So supportive. Gives me goosebumps. Twitter. Retrieved December 18, 2019, from https://witter.com/markcavendish/status/751873730775842816

Cycling News (2011, December 8). 2011 Reader Poll: Cavendish claims inaugural Twitter category. Cycling News. Retrieved December 18, 2019, from http:/www.cyclingnews.com/news/2011-reader-poll-cavendish-claims-inauguraltwitter-category

Cycling News (2012, April 25). New Twitter policy for Omega Pharma-QuickStep riders. Cycling News. Retrieved December 18, 2019, from http://www.cyclingnews.com/news/new-twitter-policy-for-omega-pharma-quickstep-riders

Dennis, M. \& Grix, J. (2014). Sport under Communism. Behind the East German 'Miracle'. Basingstoke: Palgrave Macmillan.

Feder, L. (2020). From ESPN to Instagram LIVE:The Evolution of Fan-Athlete Interaction Amid the Coronavirus. International Journal of Sport Communication. 13(3), 458-464. DOI: 10.1123/ijsc.2020-0233.

Freedom House (2019). Freedom in the World 2018: United Arab Emirates. Freedom House. Retrieved December 18, 2019, from https://freedomhouse.org/report/freedom-world/2018/united-arab-emirates

Froome, C. [@chrisfroome] (2019, February 20). Gutted to be missing the@uae tour. I was really looking forward to the TTT \& 2 uphill finishes Unfortunately I underestimated the effect training and racing at altitude would have on me this early in the season. Best of luck to the team!, Twitter. Retrieved December 18, 2019, from https://twitter.com/ chrisfroome/status/1098280017228951554

Grix, J. (2016). Sport Politics. An Introduction. Basingstoke: Palgrave Macmillan.

Goffman, E., (1956). The Presentation of Self in Everyday Life. Edinburgh: University of Edinburgh Social Sciences Research Centre.

Geurin, A. N. (2017). Elite Female Athletes' Perceptions of New Media Use Relating to Their Careers: A Qualitative Analysis. Journal of Sport Management. 31(4), 345-359. DOI: 10.1123/jsm.2016-0157.

Geurin, A. N. \& McNary, E. L. (2021). Athletes as ambush marketers? An examination of Rule 40 and athletes' social media use during the 2016 Rio Olympic Games. European Sport Management Quarterly 21(1), 116-133. DOI: 10.1080/16184742.2020.1725091.

Hamilton, L. [@LewisHamilton] (2021). Profil. Twitter. Retrieved February 20, 2021, from https://twitter.com/LewisHamilton

Halavais, A. (2014). Structure of Twitter. Social and Technical. In K. Weller, A. Bruns, J. Burgess, M. Mahrt \& C. Puschmann (Eds.), Twitter and Society (pp. 29-41). New York: Peter Lang.

Hayes Sauder, M. \& Blaszka, M. (2018). 23 Players, 23 Voices: An Examination of the U.S. Women's National Soccer Team on Twitter During the 2015 World Cup. Communication \& Sport. 6(2), 175-202. DOI: 10.1177/2167479516685579.

Highfield, T. (2014). Following the Yellow Jersey. Tweeting the Tour de France. In K. Weller, A. Bruns, J. Burgess, M. Mahrt \& C. Puschmann (Eds.), Twitter and Society (pp. 249-261). New York: Peter Lang.

Holt, R. \& Mangan, J. A., 1996. Prologue: Heroes of a European Past. In R. Holt, J. A. Mangan \& P. Lanfranchi (Eds.), European Heroes. Myth, Identity, Sport (pp. 1-13). London: Frank Cass.

Houlihan, B. (2014). The Government and Politics of Sport. London: Routledge.

Kassing J. W. \& Sanderson, J. (2010). Fan-Athlete Interaction and Twitter Tweeting Through the Giro: A Case Study. International Journal of Sport Communication. 3(3), 113-128. DOI: 10.1123/ijsc.3.1.113

Ketko, T. (2021, January 21). Rangers' Panarin shows support for Russian opposition leader Navalny. Sportsnet. Retrieved February 18, 2021, from https://www.sportsnet.ca/nhl/article/rangers-panarin-shows-support-russian-opposition-leader-navalny

Kiernan, P. (2018). Language, Identity and Cycling in the New Media Age. Exploring Interpersonal Semiotics in Multimodal Media and Online Texts. Basingstoke: Palgrave Macmillan.

Kittel, M. [@marcelkittel] (2019, February 23). Tomorrow is no time to look back anymore. theuaetourofficial starts with a TTT and @katushacycling is ready to go and have some fun. Great to be in the Emirates again. Always a good time... Twitter. Retrieved December 18, 2019, from https://twitter.com/marcelkittel/status/1099347249027575809

Kwiatkowski, M. [@kwiato] (2019, March 2). Good seven days of racing in@uae_tour@TeamSky Congratulations@rogla@therussellellis. Twitter. Retrieved December 18, 2019, from https://twitter.com/kwiato/ status/1101846707044827136

Laucella P. C. (2014). The Evolution from Print to Online Platforms for Sports Journalism. In A. C. Billings \& M. Hardin (Eds.), Routledge Handbook of Sport and New Media (pp. 89-100). London: Routledge.

Lebel, K., \& Danylchuk, K. (2012). How Tweet It Is: A Gendered Analysis of Professional Tennis Players' Self-Presentation on Twitter. International Journal of Sport Communication. 5(5), 461-480. DOI: 10.1123/ijsc.5.4.461. 
Li, B., Scott, O. K. M., Naraine, M. \& Ruihley, B. J. (2020). Tell me a story: Exploring elite female athletes' self-presentation via an analysis of Instagram Stories. Journal of Interactive Advertising. DOI: 10.1080/15252019.2020.1837038.

López-Carril, S., Escamilla-Fajardo, P., González-Serrano, M H., Ratten, V. \& González-García, R. J. (2020). The Rise of Social Media in Sport: A Bibliometric Analysis. International Journal of Innovation and Technology Management. 17(6), 1-29. DOI: 10.1142/S0219877020500418.

Marston, S. (2017). The Revival of Athlete Activism(s): Divergent Black Politics in the 2016 Presidential Election Engagements of LeBron James and Colin Kaepernick. FairPlay, Revista de Filosofia, Ética y Derecho del Deporte. 10, 45-68.

Marwick, A. \& boyd, d. (2011). To See and Be Seen: Celebrity Practice on Twitter. Convergence: The International Journal of Research into New Media Technologies. 17(2), 139-158. DOI: 10.1177/1354856510394539.

Murray, S. (2012). The Two Halves of Sports Diplomacy. Diplomacy \& Statecraft. 23(3), 576-592. DOI: 10.1080/09592296.2012.706544.

Murray, S. (2018). Sports Diplomacy. Origins, Theory and Practice. London: Routledge.

O'Shea, S. (2019, February 24). Mark Cavendish: I don't remember what it's like to feel normal anymore. Cycling News. Retrieved December 18, 2019, from http://www.cyclingnews.com/news/mark-cavendish-i-dont-remember-what-itslike-to-feel-normal-anymore

Passela, A. (2018, March 14). Abu Dhabi and Dubai cycling Tours merge to become UAE Tour from 2019 in a bid to 'create a bigger impact'. The National. Retrieved December 18, 2019, from https:/www.thenational.ae/sport/other-sport/ abu-dhabi-and-dubai-cycling-tours-merge-to-become-uae-tour-from-2019-in-a-bid-to-create-a-bigger-impact-1

Pedersen, P. M. (2014). The Changing Role of Sports Media Producers. In A. C. Billings \& M. Hardin (Eds.), Routledge Handbook of Sport and New Media (pp. 101-109). London: Routledge.

Pegoraro, A. (2010). Look Who's Talking - Athletes on Twitter: A Case Study. International Journal of Sport Communication 3 (3), 501-514. DOI: 10.1123/ijsc.3.4.501.

Pittman, M. \& Reich, B. (2016). Social Media and Loneliness: Why an Instagram Picture May Be Worth More Than a Thousand Twitter Words. Computers in Human Behavior. 62, 155-167. DOI: 10.1016/j.chb.2016.03.084

Povedák, I. (2014). From Heroes to Celebrities. Problems of definition and potential solutions. In I., Povedák (Ed.), Heroes and Celebrities in Central and Eastern Europe (pp. 7-17). Szeged: Department of Ethnology and Cultural Anthropology.

Reichart Smith, L. \& Sanderson, J. (2015). I'm Going to Instagram It! An Analysis of Athlete Self-Presentation on Instagram. Journal of Broadcasting \& Electronic Media. 59(2), 342-358. DOI: 10.1080/08838151.2015.1029125.

Sadeghi, S. \& Leng, H. K. (2020). Self-presentation of Iranian football players on Instagram during the 2018 World Cup. Soccer \& Society. DOI: 10.1080/14660970.2020.1832475

Sanderson, J. (2013). Stepping into the (Social Media) Game: Building Athlete Identity via Twitter. In R. Luppicini (Ed.), Handbook of Research on Technoself: Identity in a Technological Society (pp. 419-438). Hershey: Idea Group Global.

Sanderson, J. \& Kassing J. W. (2014). New Media and the Evolution of Fan-Athlete Interaction. In A. C. Billings \& M. Hardin (Eds.), Routledge Handbook of Sport and New Media (pp. 247-258). London: Routledge.

Schmidt, S. H., Frederick, E. L., Pegoraro, A. \& Spencer, T. C. (2019). An Analysis of Colin Kaepernick, Megan Rapinoe, and the National nthem Protests. Communication \& Sport. 7(5), 653-677. DOI: 10.1177/2167479518793625.

Sergeant, M. [@marc_sergeant] (2019, February 27). What a nice victory to start your @Lotto_Soudal palmares@CalebEwan! Well deserved after months of sacrifices and weeks of longing for this winning feeling! \#UAETour. Twitter. Retrieved December 18, 2019, from https://twitter.com/marc_sergeant/status/110073376110331904

Su, Y., Baker, B. J, Doyle, J. P. \& Kunkel, T. (2020). The Rise of an Athlete Brand: Factors Influencing the Social Media Following of Athletes. Sport Marketing Quarterly. 29 (1), 33-46. DOI: 10.32731/SMQ.291.302020.03.

Statista (2021). Most popular social networks worldwide as of January 2021, ranked by number of active users. Statista. Retrieved February 20, 2021, from https://www.statista.com/statistics/272014/global-social-networks-ranked-bynumber-of-users

Tankink, B. [@bramtankink] (2016, August 24). Ik zie@s_kruijswijk naar links gaan en ineens n enorme klap. Dit is de paal. Onzichtbaar voor n aanstormend peloton. Twitter. https://twitter.com/bramtankink/status/768488781423017984

The UAE Tour (2018, December 20). The UAE Tour 2019 - Cyclist interviews. The UAE Tour. Retrieved December 18, 2019, from https://www.theuaetour.com/gallery/the-uae-tour-2019-cyclist-interviews

The UAE Tour (2019, February 20). Provisional Entry List - 2019 UAE Tour. The UAE Tour. Retrieved December 18, 2019, from https://www.theuaetour.com/provisional-entry-list-2019-uae-tour 
UAE Team Emirates (2019a). History: The History of the team. UAE Team Emirates. Retrieved December 18, 2019, from http://www.uaeteamemirates.com/history

UAE Team Emirates [@TeamUAEAbuDhabi] (2019b, February 22). TEAM ANNOUNCEMENT We're proud to welcome@emaardubai $\square \square$ on board as a new sponsor, starting 2019. The partnership underlines Emaar's commitment to foster the local sporting scene. Full details: http://www.uaeteamemirates.com/uae-team-emirates-announce-emaarnew-sponsor/... \#UAETeamEmirates \#EmaarProperties \#EmaarDubai. Twitter. Retrieved December 18, 2019, from https://twitter.com/TeamUAEAbuDhabi/status/1098881411254288384

UAE Team Emirates [@TeamUAEAbuDhabi] (2019c, February 23). The \#UAETeamEmirates on the top of the world! Amazing scenery with our team presented on the world's tallest building, the Burj Khalifa in Dubai! @ uae_tour \#VideoOfTheDay@emirates@emaardubai@FABConnects@Colnagoworld@met_helmets@Champion_System@Elite_cycling. Twitter. Retrieved December 18, 2019, from https://twitter.com/TeamUAEAbuDhabi/ status/1099379542140116992

UAETourOfficial[@uae_tour](2019,February27).Viviani“on pointe”asever!@eliaviviani@deceuninck_qst\#UAETour \#ThePointe. Twitter. Retrieved December 18, 2019, from https://twitter.com/uae_tour/status/1100658649876385792

Valverde, A. [@alejanvalverde] (2019, February 25). Etapa muy exigente en el \#UAETour con tensión por los abánicos y el viento, bien protegido por mis compañeros de @Movistar_Team. Mañana día importante en Jebel Hafeet. Twitter. Retrieved December 18, 2019, from https://twitter.com/alejanvalverde/status/1100055387192082432

Van Reeth, D. (2016). The Finances of Professional Cycling Teams. In: D. Van Reeth \&D. J. Larson (Eds.), The Economics of Professional Road Cycling (pp. 55-82). New York: Springer.

Velon [@VelonCC] (2019, February 27). Check out the data from@JumboVismaRoad's@rogla as he increased his lead in the GC and@Lotto_Soudal's@CalebEwan as he won Stage 4 at the @uae_tour on the tough final climb. Twitter. Retrieved December 18, 2019, from https://twitter.com/VelonCC/status/1100760620188815361

Viviani, E. [@eliaviviani], (2019a, February 25). That was close but the strongest win Congrats to@FndoGaviria \#stage2 \#UAETour2019 Thanks to all my@deceuninck_qst teammates for the hard work during all the stage. Twitter. Retrieved December 18, 2019, from https://twitter.com/eliaviviani/status/1100027277935632384

Viviani, E. [@eliaviviani] (2019b, March 3). UAE tour un'altra bella settimana di lavoro, ora che la stagione Europea abbia inizio. Twitter. Retrieved December 18, 2019, from https://twitter.com/eliaviviani/status/1102061976451272704

Zákravský, J. (2016). Sport a mezinárodní vztahy. Sportovní diplomacie jako součást zahraniční politiky. Central European Journal of Politics. 2(2), 15-36.

This is Open Access article distributed under the terms of CC-BY-NC-ND 4.0 International License. 